\title{
The potential of fruit trees to enhance converted habitats for migrating birds in southern Mexico
}

\author{
MERCEDES S. FOSTER
}

\begin{abstract}
Summary
Migration routes used by Nearctic migrant birds can cover great distances; they also differ among species, within species, and between years and seasons. As a result, migration routes for an entire migratory avifauna can encompass broad geographic areas, making it impossible to protect continuous stretches of habitat sufficient to connect the wintering and breeding grounds for most species. Consequently, ways to enhance habitats converted for human use (i.e. for pasture, crop cultivation, human settlement) as stopover sites for migrants are especially important. Shelterbelts around pastures and fields, if planted with species targeted to support migrant (and resident) bird species that naturally occupy mature forest habitats and that are at least partially frugivorous, could be a powerful enhancement tool for such species, if the birds will enter the converted areas to feed. I tested this approach for Nearctic migrant birds during the spring migration through an area in Chiapas, Mexico. Mature forest tree species whose fruits are eaten by birds were surveyed. Based on life form, crop size and fruit characteristics, I selected three tree species for study: Cymbopetalum mayanum (Annonaceae), Bursera simaruba (Burseraceae) and Trophis racemosa (Moraceae). I compared the use of fruits of these species by migrants and residents in forest with their use of the fruits of isolated individuals of the same species in pasture and cropland. All three plant species were useful for enhancing converted habitats for forest-occupying spring migrants, although species differed in the degree to which they entered disturbed areas to feed on the fruits. These tree species could probably enhance habitats for migrants at sites throughout the natural geographic ranges of the plants; in other geographic areas for other target bird groups, other tree species might be more appropriate.
\end{abstract}

\section{Introduction}

Over the last two decades, ornithologists have identified various species of North American breeding birds whose populations appear to be declining (e.g. Robbins et al. 1986, 1989, Hagan and Johnston 1992, Wiedenfeld et al. 1992, Faaborg 2002). The significance of these perceived declines is unclear, however, in part because during this same period, other populations of these and other species appear to have increased (Robbins et al. 1986, Wiedenfeld et al. 1992, Peterjohn et al. 1995). Even when population changes are established, distinguishing between normal population fluctuations and true change in a species' status can be difficult, especially since population trends sometimes vary with method of data analysis (Robbins et al. 1989, Askins et al. 1990, Wiedenfeld et al. 1992). Nevertheless, several studies have shown that negative population trends for some species are real (e.g. Sauer and Droege 1992; Wiedenfeld et al. 1992, Peterjohn et al. 1995).

Among the factors most strongly implicated as potential causes of the observed declines are habitat fragmentation, degradation and loss, and their associated consequences such as increased nest predation and parasitism (Hagan and Johnston 1992, Robinson and Wilcove 1994). Significant habitat changes have occurred on both breeding and wintering grounds, although 
Stotz et al. (1996) argued that loss of habitat on the wintering grounds is an unlikely cause for current declines in most migrant species. Their assertion may be correct; however, if habitat degradation and destruction in tropical areas continue at present rates, loss of overwintering areas could have a significant negative effect on migrant populations in the future.

Less attention has been paid to the effects that habitat loss along migration routes between wintering and breeding grounds may have on bird populations (but see Barrow et al. 200o, Hutto 2000, Petit 2000). Although migrants often follow well-defined routes (flyways) during migration, those routes can differ among species, as well as within species, according to geographic location of a breeding population, sex, age, season and year (e.g. Johnson 1965, Rappole 1995, Cristol et al. 1999). Consequently, migration routes for a migratory avifauna can encompass broad geographic areas, making it impossible to protect continuous habitat to connect the wintering and breeding grounds for most species (Dobson et al. 1999). Yet migrants often need to stop en route to rest and replenish fat stores before continuing their journeys (Moore 1991, Hutto 2000), particularly species whose wintering and breeding grounds are separated by significant distances (hundreds to thousands of kilometres), or whose migratory routes cross large bodies of water lacking places to make landfall (e.g. Gulf of Mexico).

A conservation strategy for some species would be to identify and protect critical stopover sites or intermittent stepping stones of appropriate habitat along flyways (Voelker and Rohwer 1998, Dobson et al. 1999). The concentration of birds into a few areas, however, increases their vulnerability when weather conditions prevent them from reaching the next suitable site or when a natural or anthropogenic event eliminates a critical habitat patch. Species forced to occupy marginal (i.e. providing minimal food and cover for survival) or even unsuitable habitats, as opposed to optimal or preferred ones, may be more vulnerable to predation and the elements and less able to obtain the food resources necessary to complete migration and begin breeding (Moore and Aborn 2000). Given such constraints, it is important that we identify ways to enhance pastures, cropland and other converted habitats so as to maximize their utility for migrant (and resident) birds affected by the loss of the original, natural vegetation.

For centuries, forest and woodland habitats that have been converted to pasture or cropland have been enhanced for wildlife by surrounding shelterbelts, defined here as all types of vegetation planted or purposely retained around cultivated areas, including hedgerows, windrows and living fence lines (Green et al. 1994, Haas 1995). Although often established to reduce wind-generated soil erosion and moisture loss, delimit property lines or serve as fences, shelterbelts also provide homes for animals and can serve as corridors between habitat patches (Haas 1995, Dobson et al. 1999). The diversity of plant species included in planted shelterbelts is generally low, and in unmanaged natural shelterbelts, plant species characteristic of early succession often predominate (Warkentin et al. 1995, Dobson et al. 1999). Yet among the birds and other animals most affected by loss of habitat are those that occupy very late successional and mature forest habitats, which are disappearing rapidly, particularly in tropical and subtropical areas. In this study, I examine how the plant composition of shelterbelts might be managed to enhance the utility of converted habitats for Nearctic migrant songbirds that occupy mature habitats during the spring (northward) migration, as well as for local species resident in the same mature habitats.

Stopover areas are most important to migrants as a source of food for replenishing energy stores (Moore 1991, Hutto 2000). Many species of songbirds that migrate between temperate North America and the Neotropics, although primarily insectivorous during the breeding season, eat significant quantities of fruit during migration and on the wintering grounds (Morton 1980, Rappole et al. 1983, Greenberg et al. 1995, Rappole 1995, Parrish 2000, M. S. F., unpubl. data). If forest trees whose fruits are key resources for migrating birds could be identified and included in shelterbelts, then theoretically they could provide food and shelter in areas where mature forest has been converted to agriculture or settlements. On the other hand, if birds accustomed to feeding in mature forest habitats will not visit or feed in isolated trees or strips of trees in converted areas, then the efforts required to create shelterbelts customized for 
forest-occupying migrants might best be directed elsewhere.

I addressed these issues in March and April 1991 to 1993 at a site in south-eastern Mexico through which many Nearctic migrants pass on their way north (González-García 1992, R. Greenberg, unpubl. data, M. S. F., pers. obs.). My assistants and I ascertained which tree species in mature forest habitats produce fruits that are important food resources for late-winter birds building fat reserves and spring migrants, as well as suitable for shelterbelts. We then located isolated trees of those species in areas where the forest had been cleared and the land converted to human uses. We observed individuals of each tree species both in the forest and in converted areas in order to compare fruit-use by birds in the two areas and determine the degree to which forest species might venture into converted habitats to feed.

\section{Study area}

The study sites are located in the Marqués de Comillas Zone, state of Chiapas, Mexico. The Chajul Tropical Biology Station (c. $16^{\circ} 06^{\prime} \mathrm{N}, 90^{\circ} 56^{\prime} \mathrm{W}$; elevation c. $161 \mathrm{~m}$; Google Earth 2006) is located in the south-central part of the Lacandon forest on the north bank of the Lacantún River in the Montes Azules Biosphere Reserve (Vásquez Sánchez 1992: figs.1-2). We worked in tall, evergreen rain forest (Castillo-Campos and Narave Flores 1992 [Tropical Lowland Evergreen Forest, $F_{1}$ of Stotz et al.1996]) within approximately $8 \mathrm{~km}$ upstream and $2 \mathrm{~km}$ downstream from the station. The forest was generally free of human disturbance, although limited patches of second growth were evident in areas cleared for agriculture in the 1970s and 1980s and then abandoned. Forest areas along the river are relatively flat and periodically flooded. As one moves north or north-west from the river, the land slopes upward (either gently or steeply) over successive ridges cut by stream ravines. Our study areas were located only about $100 \mathrm{~m}$ above the floodplain. For ease of reference I refer to the forested slopes and ridges where we worked as 'upland', and the forest in the flat areas along the river as 'lowland' or floodplain, the latter including low lying 'riverine' areas that were extremely disturbed by flood waters when the Lacantún River overflowed its banks.

Tropical rain forest is one of the most threatened habitats in Mexico. The Montes Azules Reserve incorporates one of the last remaining areas of this habitat in the country and has been designated an 'Important Area for Bird Conservation' (AICA SE-17; González García and Rangel Salazar 1999). It is home to 1o bird species that are Threatened, Endangered or Vulnerable for the country, and another four species that are Threatened, Endangered or Vulnerable globally.

Observations made at trees of selected forest species were compared with those made at conspecific trees in or near the ejidos (communal lands) of Chajul and Loma Bonita, located on the south bank of the Lacantún River. Chajul (elevation $c$. $150 \mathrm{~m}$ ) lies approximately $1.6 \mathrm{~km}$ downstream and Loma Bonita (elevation c. $166 \mathrm{~m}$ ) approximately $7.9 \mathrm{~km}$ upstream from the station (Google Earth 2006). The ejidos and vicinity are characterized by extensive pastures, agricultural fields with subsistence crops and commercially grown jalapeño chillies, a few small cacao plantations and some young second-growth forest. Large trees have been removed from remaining patches of mature forest and second-growth forests, and understorey vegetation has been degraded by cattle. The area is described in Vásquez Sánchez \& Ramos Olmos (1992). Annual rainfall is about $3,000 \mathrm{~mm}$, with a wet season from May to November (Fragoso and Lavelle 1987).

\section{Methods}

\section{Fruit availability}

Fruit availability was surveyed at approximately 2-week intervals. In forest habitats we carried out 30 surveys (two in 1991, 15 in 1992 and 13 in 1993) of fruiting trees and shrubs within $5 \mathrm{~m}$ on either side of six transects totalling $5 \mathrm{~km}$, as follows: two $\mathrm{I} \mathrm{km}$ transects through upland 
forest; two (1.0 and $0.5 \mathrm{~km}$ ) in riverine forest; and two (1.0 and $0.5 \mathrm{~km}$ ) in flat, generally nonflooded, lowland forest.

We estimated crop size on a tree by counting the number of fruits on racemes or twigs, the number of racemes or twigs on small branches, the number of small branches on large branches and the number of large branches per tree, and then multiplying the values. For plants with dehiscent fruits containing numerous arillate seeds that are removed individually by birds, we multiplied the number of fruits by the average number of arillate seeds per fruit to provide the number of 'feeding units' on a tree. We also estimated the percentage of the crop that was ripe. Because of dense vegetation and inconspicuousness of some fruits, estimates are, at best, approximations. Voucher specimens were collected for all species.

Fruits of each tree were described, weighed and measured. Fruit pulp samples were collected and dried. I use the term 'pulp', generically, to refer to the fleshy material surrounding a seed that is consumed by frugivorous birds; it does not include fleshy or hard protective structures. Nutrient (lipid, protein, soluble carbohydrate, ash and calcium) content was analysed by the Palmer Laboratory, the University of Alaska, Fairbanks (see Greenberg et al. 1995 for detailed methods). I estimated available (metabolizable) energy content per pulp per fruit using values of $39.75 \mathrm{~kJ}(9.5 \mathrm{kcal}) \mathrm{g}^{-1}$ lipid, $23.64 \mathrm{~kJ}(5.65 \mathrm{kcal}) \mathrm{g}^{-1}$ protein and $17.15 \mathrm{~kJ}(4.1 \mathrm{kcal}) \mathrm{g}^{-1}$ soluble carbohydrate (Paine 1971).

\section{Selection of plant study species}

More than 70 species with ripe fruits were recorded during the surveys (M. S. F., unpubl. data). I evaluated their potential as habitat enhancers based on the following criteria:

(I) Suitability of the life form for use in hedgerows or living fence rows, or as shade trees or ornamentals. Small to moderate size, firmly anchored, moderate to fast growing and moderate to long-lived trees were deemed appropriate. I eliminated vines, shrubs, canopy and emergent trees, slow-growing palms, and weakly anchored and short-lived trees from further consideration.

(2) Suitability of fruits as foods for a broad range of birds. I considered fruits with moist; fleshy; red, purple, or black (Turček 1963) pulp that were small enough $(\leqslant 15 \mathrm{~mm}$ diameter) to be consumed by birds of many different sizes to be most appropriate.

(3) Large crop size $(\geqslant 2000)$, with good quantities of ripe fruits present for $4-6$ weeks. Tree species that produce large fruit crops every year on a fairly regular schedule maximize the number of birds that can be fed as well as the temporal and spatial predictability of the resource. Such species should accommodate the needs of large waves of migrants better than species whose individual plants provide only a few fruits or feeding units each day, although over a longer period.

(4) Commonness of fruiting trees in the forest. I assumed that many birds would already be accustomed to feeding on fruits of the more common trees.

Only seven of the 70 species met criteria 1 and 2. Based on criteria 3 and 4 , I selected three of those as study species: Cymbopetalum mayanum (Annonaceae), Bursera simaruba (Burseraceae) and Trophis racemosa (Moraceae). Although crop size in a C. mayanum in forest is only about 1,000 feeding units per season, trees in open, sunny areas produce 6 to 8 times that amount. We next searched until we located lone individuals of these species in pastures, croplands and settlements.

\section{Bird observations}

We observed fruit eating by birds during March and April, 1991 to 1993. These months encompass the end of the premigration period during which wintering birds build energy reserves in anticipation of their northward flights, as well as the peak of songbird migration 
through the area (R. Greenberg, pers. com.; M. S. F., pers. obs.). We observed five individuals of C. mayanum in upland and riverine forest for a total of $73 \mathrm{~h}$ and two individuals in disturbed areas (scrub along a pasture airstrip and a cacao plantation) for $60 \mathrm{~h}$. We observed seven trees of B. simaruba, two in undisturbed and five in disturbed habitats (scrub and pastures), for $47 \mathrm{~h}$ and $52.5 \mathrm{~h}$, respectively. We observed four trees of T. racemosa, one in upland and one in lowland forest, for $17 \mathrm{~h}$ and two in disturbed areas (pasture edge and a cornfield) for $50 \mathrm{~h}$, for a total of $67 \mathrm{~h}$. Variation in observation hours reflects fruit availability of the species in different habitats.

Observations were made with binoculars between 06 hoo and 13 hoo and between 15 hoo and 17 ho. Each bird that ate fruit was identified to species, and the number of fruits it consumed and its feeding behaviour were recorded. Only data from bird species responsible for $\geqslant 5 \%$ of all bird visits to a particular plant species and/or for eating $\geqslant 5 \%$ of all fruits consumed were analysed. Scientific and common names of all bird species observed are given in the Appendix and follow the $7^{\text {th }}$ edition of Check-list of North American Birds (American Ornithologists' Union 1998).

\section{Results}

\section{Cymbopetalum mayanum}

Cymbopetalum mayanum occurs from south-eastern Mexico to north-western Honduras at elevations of 100-600 m (Murray 1993), occupying late second-growth and mature wet tall or medium forest. Cymbopetalum trees were found in all forest types in the study area. Ripe fruits were available from March to early May (occasionally into June), but were most abundant in April. Within a tree, fruits ripened asynchronously over a 6-8 week period, depending on crop size. These mid-storey trees can reach $25 \mathrm{~m}$ in height and $40 \mathrm{~cm}$ diameter at breast height (DBH) (Murray 1993).

The fruits of $C$. mayanum are apocarpous, with a cluster of monocarps (up to 20 per cluster recorded) arising from a central receptacle (Grissell and Foster 1996: fig. 27). Ripening of the monocarps within a cluster is asynchronous. The monocarps have a thick, hard rind. When ripe, they dehisce along the abaxial surface, exposing from 6 to 19 (mean 14.5, $n=23$ ) very dark purplish-black arillate seeds partially embedded in a cream-coloured, fleshy parenchyma that fills the interior of the monocarp. About $75 \%$ of the surface of each seed is covered by a bright red-orange, oily aril that is easily removed. Seeds are small with relatively limited amounts of aril (Table 1). However, that pulp is high in lipid and energy-rich (Table 1 ).

Table 1. Selected characteristics of fruits of Cymbopetalum mayanum, Bursera simaruba and Trophis racemosa in the vicinity of the Chajul Tropical Biology Station, Chiapas, Mexico.

\begin{tabular}{|c|c|c|c|c|c|}
\hline & $\begin{array}{l}\text { Seed width } \\
\quad(\mathrm{mm})\end{array}$ & $\begin{array}{c}\text { Pulp: dry } \\
\text { wt/seed (mg) }\end{array}$ & $\begin{array}{l}\text { Pulp: \% dry } \\
\text { wt lipid }\end{array}$ & $\begin{array}{c}\text { Pulp: \% dry wt } \\
\text { non-structural } \\
\text { carbohydrate }\end{array}$ & $\begin{array}{c}\text { Metabolizable } \\
\text { energy per pulp } \\
\text { per seed }(\mathrm{kJ})\end{array}$ \\
\hline \multicolumn{6}{|c|}{ C. mayanum $^{\mathrm{a}}$} \\
\hline $\begin{array}{l}\text { Mean } \pm \text { SD } \\
(n)\end{array}$ & $7 \cdot 7 \underset{(162)}{ \pm 0.70}$ & $69 \underset{(I I)}{ \pm} 4.0$ & $\begin{array}{c}53.6 \\
(4)\end{array}$ & $\begin{array}{l}5 \cdot 7 \\
(4)\end{array}$ & $\begin{array}{l}1.54 \\
(4)\end{array}$ \\
\hline \multicolumn{6}{|c|}{ B. simarubab } \\
\hline $\begin{array}{l}\text { Mean } \pm \text { SD } \\
(n)\end{array}$ & $\begin{array}{c}5 \cdot 3 \pm 0.55 \\
(132)\end{array}$ & $29 \pm \frac{10.5}{(17)}$ & $\begin{array}{c}47.1 \\
(1)\end{array}$ & $\begin{array}{l}1.2 \\
(1)\end{array}$ & $\begin{array}{l}0.56 \\
(1)\end{array}$ \\
\hline \multicolumn{6}{|c|}{ T. racemosa } \\
\hline $\begin{array}{l}\text { Mean } \pm \text { SD } \\
(n)\end{array}$ & $\begin{array}{c}6.0 \pm 0.99 \\
(20)\end{array}$ & $97 \underset{ \pm 25.5}{(20)}$ & $\begin{array}{l}2.9 \\
(2)\end{array}$ & $\begin{array}{l}35.0 \\
(2)\end{array}$ & $\begin{array}{l}0.88 \\
(2)\end{array}$ \\
\hline
\end{tabular}

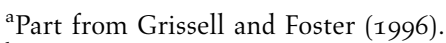

bPart from Greenberg et al. (1995). 
Crop sizes of trees growing in open, converted habitats ranged from 6,000 to 8,ooo seed-aril units per tree per season, depending on both tree size and amount of sunlight, with a maximum of $c .350$ available on a single day. Some fruits still contained seed-aril units as it got dark. Trees in the forest had smaller crops, with an estimated maximum of up to 1,0oo seed-aril units per tree per season. On those trees many fewer monocarps opened each day and usually, all seed-aril units had been removed by early afternoon.

Forty-one bird species, including 16 Nearctic migrant species, ate Cymbopetalum fruits (Table 3, Appendix). More species ate Cymbopetalum fruits in disturbed than undisturbed areas and they also ate it more frequently (Tables 2,3 ). In each habitat, a small number of bird species accounted for nearly $75 \%$ of the visits and removed $61-73 \%$ of all fruits taken (Table 4 ). Three of those species were the same in both habitats. All species, except the Red-throated Anttanager, are Nearctic migrants.

\section{Bursera simaruba}

Bursera simaruba trees are distributed from southern Florida, through Mexico, Central America and the West Indies, to northern South America (Little and Wadsworth 1964, Croat 1978). The trees are common and grow in a wide range of habitats. Bursera trees in the study area were located in upland, lowland and riverine forests, and are especially common along the banks of the

Table 2. Rates at which birds visit ${ }^{\mathrm{a}}$ and take fruits from trees of Cymbopetalum mayanum, Bursera simaruba and Trophis racemosa in undisturbed and disturbed habitats in the vicinity of Chajul Tropical Biology Station, Chiapas, Mexico.

\begin{tabular}{lccc}
\hline Habitat & C. mayanum & B. Simaruba & T. racemosa \\
\hline Undisturbed & & & \\
$\quad$ Mean no. visits per hour observation & 3.1 & 1.8 & 3.5 \\
Mean no. fruits removed per hour & 4.3 & 2.7 & 6.1 \\
Disturbed & & & \\
$\quad$ Mean no. visits per hour observation & 7.2 & 4.6 & 3.4 \\
Mean no. fruits removed per hour & 10.5 & 10.4 & 7.2 \\
\hline
\end{tabular}

${ }^{a}$ Only visits during which a bird consumed a fruit are included.

Table 3. Use of Cymbopetalum, Bursera and Trophis fruits by species of birds in undisturbed and disturbed habitats in the vicinity of Chajul Tropical Biology Station, Chiapas, Mexico.

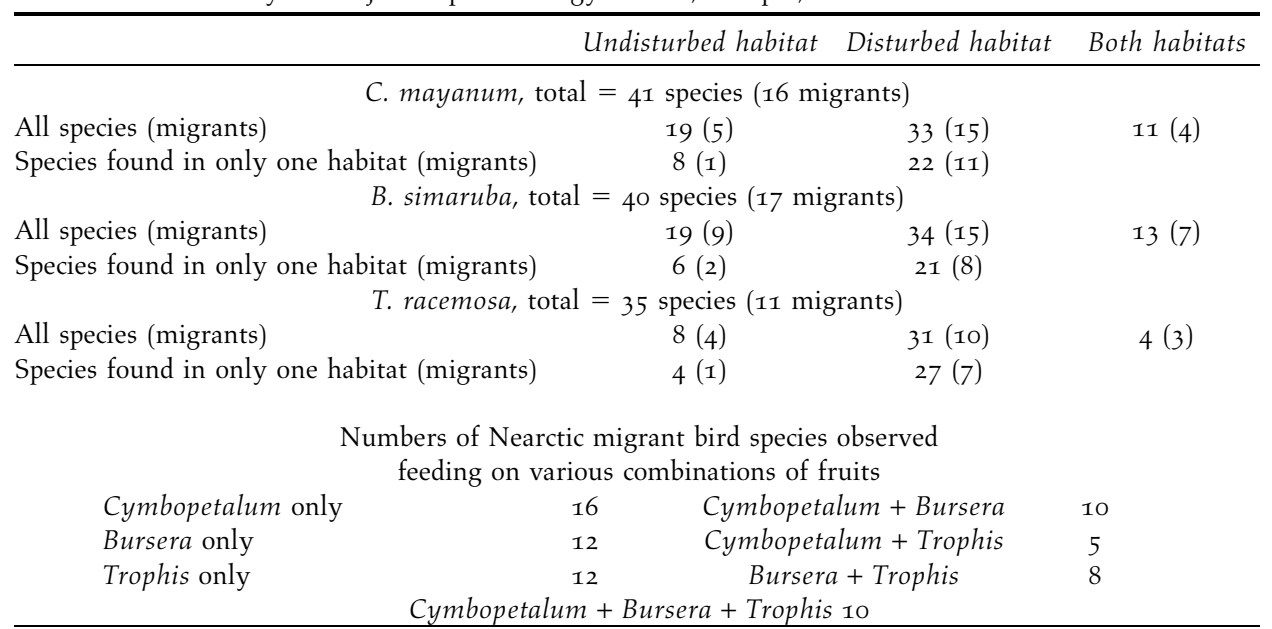


Table 4. Most frequent avian consumers ${ }^{\mathrm{a}}$ of Cymbopetalum mayanum fruits in undisturbed and disturbed areas in the vicinity of the Chajul Tropical Biology Station, Chiapas, Mexico.

\begin{tabular}{|c|c|c|c|c|}
\hline \multirow[t]{2}{*}{ Bird Species ${ }^{\mathrm{b}}$} & \multicolumn{2}{|c|}{ Undisturbed forest } & \multicolumn{2}{|c|}{ Disturbed areas } \\
\hline & $\begin{array}{l}\% \text { all bird } \\
\text { visits }^{c}\end{array}$ & $\begin{array}{l}\% \text { all fruits } \\
\text { eaten }^{\mathrm{d}}\end{array}$ & $\begin{array}{l}\% \text { all bird } \\
\text { visits }^{\mathrm{e}}\end{array}$ & $\begin{array}{l}\% \text { all fruits } \\
\text { eaten }{ }^{f}\end{array}$ \\
\hline Swainson's Thrush* & 11 & 11 & & \\
\hline Red-throated Ant-tanager & 9 & 9 & & \\
\hline Kentucky Warbler* & 6 & $-\mathrm{g}$ & & \\
\hline Summer Tanager* & 22 & 17 & 27 & 20 \\
\hline Wood Thrush* & 18 & 16 & 13 & 16 \\
\hline Grey Catbird* & 8 & 8 & 23 & 29 \\
\hline Chestnut-sided Warbler* & & & 12 & $8^{h}$ \\
\hline
\end{tabular}

${ }^{\mathrm{a}}$ Includes all species making $\geqslant 5 \%$ of the visits or consuming $\geqslant 5 \%$ of the fruits eaten.

${ }^{\mathrm{b}}$ Asterisk denotes Nearctic migrant.

${ }^{\mathrm{c}} n=226$ visits.

$\mathrm{d}_{n}=311$ seed-aril units eaten.

${ }^{\mathrm{e}} n=431$ visits.

${ }^{\mathrm{f}} n=629$ seed-aril units eaten.

${ }^{g}$ Unable to quantify: birds ate parenchyma tissue and pieces of pulp from multiple seeds in situ.

Lacantún River and its tributaries, where they can reach heights of $30 \mathrm{~m}$ and a DBH of $1 \mathrm{~m}$. Crops on large trees can number 15,000 fruits or more. However, most of the forest trees we encountered had crop sizes of 5,000 or fewer; crop sizes of isolated trees in disturbed areas were considerably smaller, primarily a reflection of smaller tree size. At least a few ripe fruits were present each month, with peak abundance in March and April (M. S. F., unpubl. data).

Fruits are small and consist of a three-valved capsule encasing a single small seed (Table $\mathrm{I}$ ) covered by a red aril. The capsule on ripe fruit can be opened by birds (e.g. Greenberg et al. 1995), or it may dehisce on its own. Most frequently, capsules are opened by birds. The amount of aril per seed is limited, but the tissue is lipid-rich (Table 1 ).

Forty species of birds, including 17 species of Nearctic migrants, ate Bursera fruits (Table 3, Appendix). As with Cymbopetalum, more bird species and individuals visited and fed on Bursera fruits in disturbed than in undisturbed habitats (Table 2, Appendix). Thirteen bird species ate Bursera fruits in both habitats. Eight species (including three migrants) were responsible for more than $75 \%$ of the visits to Bursera in undisturbed forest and accounted for more than $75 \%$ of the fruits eaten (Table 5). In disturbed areas, eight species (including six migrants) were responsible for more than $60 \%$ of the visits and fruits consumed. Only three of those species (all migrants) were recorded in both areas (Table 3 ).

\section{Trophis racemosa}

Trophis racemosa occupies mesic upland and riparian medium and tall forests from Mexico to Peru and Brazil, and the Greater Antilles (Pennington and Sarukhan 1968, Croat 1978, N. V. L. Brokaw, E. P. Mallory and P. W. Alcorn, unpubl. data). This small to medium-size mid-canopy tree reaches a height of $25 \mathrm{~m}$ and DBH of $50 \mathrm{~cm}$ (Standley and Steyermark 1946), although trees in Mexico are reportedly smaller (Pennington and Sarukhan 1968). Trees were present in all forest habitats where we worked but were less common than the other two species.

The fruits are small, spherical to slightly elongate, fleshy, single-seeded drupes (Table 1). They are soft when ripe, bright rosy red, and densely covered with fine hairs. Crop size ranged up to about 10,000 fruits and ripe fruits were available from February to April, generally with a peak in March. Trophis pulp contains much less lipid than the pulp of the other two species. However, the amount of soluble carbohydrate in the pulp and the amount of pulp per seed are 
Table 5. Most frequent avian consumers ${ }^{\mathrm{a}}$ of Bursera simaruba fruits in undisturbed and disturbed areas in the vicinity of the Chajul Tropical Biology Station, Chiapas, Mexico.

\begin{tabular}{|c|c|c|c|c|}
\hline \multirow[t]{2}{*}{ Bird species $^{b}$} & \multicolumn{2}{|c|}{ Undisturbed forest } & \multicolumn{2}{|c|}{ Disturbed areas } \\
\hline & $\begin{array}{l}\% \text { all bird } \\
\text { visits }^{c}\end{array}$ & $\begin{array}{l}\% \text { all fruits } \\
\text { eaten }^{d}\end{array}$ & $\begin{array}{l}\% \text { all bird } \\
\text { visits }^{\mathrm{e}}\end{array}$ & $\begin{array}{l}\% \text { all fruits } \\
\text { eaten }\end{array}$ \\
\hline Masked Tityra & 16 & 21 & & \\
\hline Bright-rumped Attila & 11 & 12 & & \\
\hline Black-faced Grosbeak & 11 & 10 & & \\
\hline Rufous Mourner & 8 & 6 & & \\
\hline Black-crowned Tityra & 6 & 6 & & \\
\hline Baltimore Oriole* & 12 & 8 & 10 & 7 \\
\hline Red-eyed Vireo* & 9 & 10 & 14 & 13 \\
\hline Yellow-throated Vireo* & 5 & 4 & 8 & 7 \\
\hline Dusky-capped Flycatcher* & & & 9 & 9 \\
\hline Rose-breasted Grosbeak* & & & 8 & 7 \\
\hline Social Flycatcher & & & 7 & 5 \\
\hline Brown-crested Flycatcher* & & & 6 & 5 \\
\hline Red-lored Parakeet & & & 1 & 10 \\
\hline
\end{tabular}

${ }^{\mathrm{a}}$ Includes all species making $\geqslant 5 \%$ of the visits or consuming $\geqslant 5 \%$ of the fruits eaten.

${ }^{\mathrm{b}}$ Asterisk denotes Nearctic migrant.

${ }^{\mathrm{c}} n=85$ visits.

$\mathrm{d}_{n}=126$ seed-aril units eaten.

${ }^{\mathrm{e}} n=243$ visits.

${ }^{\mathrm{f}} n=544$ seed-aril units eaten.

considerably greater, which boosts the energy content per pulp per fruit (Table 1 ).

Trophis fruits were eaten by fewer species of birds (24 residents and II migrants) than either Cymbopetalum or Bursera (Table 3, Appendix). Only eight species ate Trophis in the forest; of those, five species made $95 \%$ of the visits and consumed $98 \%$ of the fruit removed (Table 6). In contrast, 31 species of birds ate Trophis in disturbed areas, but the top six consumer species made $72 \%$ of the visits and ate $76 \%$ of the fruits consumed (Table 6). Visits per hour and fruits removed per hour were approximately the same in both habitats (Table 2).

\section{Overlap in fruit use}

Cymbopetalum fruits were eaten by 41 (56\%) of the 73 species we observed eating fruits of any of the three species, Trophis fruits were eaten by 35 (48\%) of those species and Bursera fruits by 40 (55\%; cf. Scott and Martin 1984 and Graham et al. 2002, who both reported 39 species feeding on Bursera fruits, and Greenberg et al. 1995, who reported 20). Forty (55\%) of the bird species ate only one species of fruit, $23(32 \%)$ ate two species and only 1o species (14\%) ate fruits of all three trees (Table 3, Appendix).

\section{Discussion}

\section{Fruit use by birds}

The numbers of species of birds feeding on fruits of each of the three plant species were similar. The differences in visitors among the tree species and the absence from these trees of at least some of the other local frugivores (González-García 1992) may reflect, in part, differences in fruit size, as well as differences in the ways in which they are presented on the tree. Trophis fruits are too large (diameter $c$. $10 \mathrm{~mm}$, Table 1 ) to be removed and swallowed whole by many of 
Table 6. Most frequent avian consumers ${ }^{\mathrm{a}}$ of Trophis racemosa fruits in undisturbed and disturbed areas in the vicinity of the Chajul Tropical Biology Station, Chiapas, Mexico.

\begin{tabular}{|c|c|c|c|c|}
\hline \multirow[t]{2}{*}{ Bird Species ${ }^{b}$} & \multicolumn{2}{|c|}{ Undisturbed forest } & \multicolumn{2}{|c|}{ Disturbed areas } \\
\hline & $\begin{array}{l}\% \text { all bird } \\
\text { visits }^{c}\end{array}$ & $\begin{array}{l}\% \text { all fruits } \\
\text { eaten }^{d}\end{array}$ & $\begin{array}{l}\% \text { all bird } \\
\text { visits }^{\mathrm{e}}\end{array}$ & $\begin{array}{l}\% \text { all fruits } \\
\text { eaten }^{f}\end{array}$ \\
\hline Swainson's Thrush* & 70 & 60 & & \\
\hline Wood Thrush* & 8 & 11 & & \\
\hline Summer Tanager* & 7 & 5 & & \\
\hline Crimson-collared Tanager & 5 & 13 & & \\
\hline Gray Catbird* & 5 & 9 & 17 & 11 \\
\hline Northern Oriole & & & 19 & 30 \\
\hline Rose-breasted Grosbeak ${ }^{*}$ & & & 12 & 9 \\
\hline Clay-coloured Robin & & & 12 & 8 \\
\hline Orchard Oriole* & & & 6 & 12 \\
\hline Brown Jay & & & 6 & 6 \\
\hline
\end{tabular}

${ }^{a}$ Includes all species making $\geqslant 5 \%$ of the visits or consuming $\geqslant 5 \%$ of the fruits eaten.

${ }^{\mathrm{b}}$ Asterisk denotes Nearctic migrant.

${ }^{\mathrm{c}} n=59$ visits.

$\mathrm{d}_{n}=104$ fruits eaten.

${ }^{\mathrm{e}} n=170$ visits.

${ }^{\mathrm{f}} n=362$ fruits eaten.

the smaller fruit-eating birds in the area (e.g. manakins, warblers and vireos). Although individuals of many species of small birds perch near large fruits and remove successive small bites of pulp, feeding in this manner is relatively inefficient (Foster 1987). Consequently, feeding bouts are longer or more frequent, increasing the vulnerability of small birds to predators (Howe 1979, Woodrey 2000).

The capsules of seemingly mature Bursera fruits remain closed for some indeterminate period before opening. Capsules of ripe fruits, which are indistinguishable to a human eye from those of unripe fruits, fall away easily when lightly squeezed or tapped. Birds (both individuals and species) differ significantly in their abilities to detect which closed-capsule fruits are ripe (Greenberg et al. 1995; M. S. F., unpubl. data). Because fruit-ripening on a tree is asynchronous, birds of some species can spend considerable time tapping or squeezing fruits before locating a ripe one. Species of birds that are especially poor at detecting ripe fruits may avoid feeding in Bursera until the capsules dehisce naturally.

Although some birds reach to remove Bursera and Cymbopetalum feeding units while perched on the fruit or on an adjacent branch, many birds either hover to remove them or snatch them as they fly by. Some bird species rarely or never use the latter two foraging methods. Thus, they may be less likely to consume these fruits, although the foraging behaviours of many migratory birds are flexible (Martin and Karr 1990, Parrish 2000).

In addition to differences in numbers of bird species visiting, the tree species differed greatly in the rates at which they were visited by individuals, although no consistent pattern was apparent. Because Trophis and Bursera pulp contained only about $57 \%$ and $37 \%$, respectively, of the energy in Cymbopetalum pulp (Table I), I hypothesized that the latter species would be visited by more birds and more species in all habitats. Cymbopetalum was visited most frequently in both disturbed habitats and overall (results from both habitats combined). Trophis was visited most frequently in undisturbed habitats, which may reflect its larger crop size, since birds tend to visit patches with the greatest concentrations of resources (Martin and Karr 1986, Rey 1995, Borgmann et al. 2004). All available feeding units were generally removed from Cymbopetalum fruits in undisturbed habitats by early afternoon whereas ripe Trophis fruits were continuously available on the tree for the length of the fruiting period. Despite the lower 
energy content of its fruit and the need for birds to learn to discriminate fruit ripeness, Bursera was visited more often than Trophis in disturbed habitats. Differences in rates of visitation to the different trees may reflect differences in the densities and spatial distributions of the trees and/or differences in abundances of the bird species feeding on their fruits.

Six $(86 \%)$ of the seven species making $\geqslant 5 \%$ of all feeding visits to Cymbopetalum or eating $\geqslant 5 \%$ of all fruits consumed were Nearctic migrants; for Bursera, only six $(44 \%)$ of 13 species were migrants and for Trophis seven $(70 \%)$ of 10 species were migrants. It may be that birds laying down fat reserves for migration or replenishing them at stopover sites are more likely to feed on fruits with high-energy pulp than are resident forms. In addition, when results for the three fruit species are combined, the six bird species that ate the greatest number of fruits were all Nearctic migrants (in decreasing order by amount eaten): Swainson's Thrush, Gray Catbird, Baltimore Oriole, Wood Thrush, Summer Tanager, Red-eyed Vireo. Together, they ate nearly half $(48 \%)$ of all the fruit consumed, which illustrates the importance of fruit to at least some species of Nearctic migrants (Parrish 2000, Graham et al. 2002), even though all species in that group except the Wood Thrush are rated as of 'low' conservation priority; the Wood Thrush is rated 'medium' (Stotz et al. 1996). Nearctic migrants are also clearly important to least some species of Neotropical trees as seed dispersers (cf. Greenberg et al. 1995).

\section{Habitat use by birds}

Stotz et al. (1996) designated 63 of the 73 species that we observed eating fruits of one or more of the study species as primarily forest-dwellers, nine (four migrants) as using both forest and scrub habitats and one as a marsh species. On the other hand, we observed 23 of those species (including 11 migrants) eating fruits in both undisturbed and disturbed areas, but only two (both migrants) were among the nine reported (Stotz et al. 1996) to use both forest and scrub habitats. These values suggest that a large proportion of migrating (and wintering) birds ( 11 of 26, 42\%) that normally occupy forest habitats will feed in converted habitats such as pastures and croplands. Resident species were less flexible; only 12 of $47(26 \%)$ fed in both habitats. R. Greenberg (unpubl. data), who censused winter birds in nine undisturbed (forest) and disturbed habitats around Chajul and Montes Azules, noted broad use of both habitats by about one-third of the species he recorded. Gonzáles-Garcia (1992), who also recorded birds in forest and open habitats in the area, obtained similar results.

Habitat plasticity among migrant birds, especially species that breed in forest habitats, is well known, and birds can occupy a wider range of habitats during migration if appropriate food resources are available (Greenberg 1992, Petit 2000). In some species of migrants that occupy winter territories, dominant individuals force less dominant conspecifics (often females and firstyear birds) to occupy less desirable habitats (Moore and Aborn 2000, Woodrey 200o).

Use of both habitat types could also reflect the way that I classified the habitats. I included both degraded river-edge vegetation adjacent to cultivated fields and closed-canopy cacao plantations in my 'disturbed habitat' category, along with pastures, croplands and scrubby second growth (second-growth scrub, N14 of Stotz et al. 1996). Habitats with continuous tree cover, even if significantly altered, are probably more acceptable to forest birds than those without it (Greenberg et al. 1997). Graham et al. (2002), for example, found little difference among the birds feeding on Bursera in disturbed and continuous habitats at a site in Veracruz, Mexico, between December and March. However, their disturbed habitats were remnants of riparian forest represented by 'thin (10-50 m wide) lines of trees' (Graham et al. 2002: 590).

\section{Tree survival}

We found several individuals of each of the three study-tree species growing in disturbed areas, such as the middle of a pasture or in a cacao plantation, even though their natural habitat is forest. They all seemed healthy and robust and tended to reach larger sizes and have larger fruit 
crops than trees in the forest, perhaps in response to increased sunlight. People have used all three species for various purposes in the past and may still do so, especially in areas where access to manufactured goods is limited.

Fruits of T. racemosa reportedly are edible (Miranda 1953), but I am unaware of anyone in the area eating them or the fruits of the other species. Various preparations of parts of all the species and/or their close relatives have been used to treat a wide range of medical conditions, including snake bite (Miranda 1953, Martinez 1969, Pulido Salas and Serralta Peraza 1993). The wood of $B$. simaruba is suitable for light construction and fuel, and the resin is used as glue, varnish and incense. The bark of C. mayanum can be used to make rope (Miranda 1953, Little and Wadsworth 1964, Murray 1993).

A few other uses of these trees may increase their value to local people even more. Branches and leaves of $T$. racemosa are sometimes fed to livestock during the dry season when other forage is unavailable (Miranda 1953, Little et al. 1974). Bursera trees are also widely used as living fence-posts in other parts of Mexico, Central America and the Caribbean, apparently because these fast-growing trees regenerate without any care from fresh limbs stuck in the ground (Little and Wadsworth 1964; M. S. F., pers. obs.).

Despite their countless uses, with the exception of a single, large individual of $T$. racemosa that may have been retained to shade an outdoor work area, the presence of the study-species trees that we observed in the disturbed habitats appears to have been serendipitous rather than planned. Reminding a community of some of these uses may make the use of the trees in shelterbelts more attractive. In the meantime, a great deal of information about propagation and survival of these species (especially $T$. racemosa and C. mayanum) in disturbed areas will be required to determine their suitability for use in shelterbelts.

\section{Habitat enhancement}

Cymbopetalum mayanum, B. simaruba and T. racemosa appear to be excellent candidate species for enhancing converted habitats around Chajul and its neighbouring ejidos for migrant birds. Many resident species also ate their fruits although the primary consumers were Nearctic migrants preparing for or undertaking their northward migration. None of the species (migrant or resident) that we recorded was considered by Parker et al. (1996) to be of urgent or high 'Conservation Priority' or of high 'Research Priority', although six and seven species were rated of medium priority in the two categories, respectively. The point of management, whenever possible, however, should be to prevent species from reaching threatened or endangered status rather than to rescue them once they have arrived.

These plants could be used in shelterbelts throughout their geographic ranges to enhance disrupted habitats for the bird species we recorded or for other migratory, wintering or resident bird species (e.g. Scott and Martin 1984, Graham et al. 2002). In other geographic areas or with other target groups of birds, other tree species might be more appropriate (cf. Coates-Estrada and Estrada 1988, Graham et al. 2002). If the food preferences of avian frugivores were known, then a manager could tailor the plant composition of a shelter belt to target particular species or the entire frugivorous avifauna of an area. Enhancement of this type need not be constrained by season or residency status of the birds. A shelterbelt could include plant species critical to any or all groups of birds at any or all times of year. One can envision shelterbelts planted with repeating series of the most important tree species that fruit in sequence over a 12-month period. Spaces between trees could be planted with shrubs (e.g. species of Psychotria, Miconia, Xylopia) that also produce fruits regularly consumed by birds.

Attempts could also be made to select trees whose fruits provide a variety of important nutrients. Fruits that have a high energy content may meet the needs of birds preparing for or engaged in particularly energy-demanding activities such as migration and decrease the length of a stopover period. Fruits rich in a potentially limiting substance (e.g. water, protein, calcium) 
might significantly supplement the diet of birds with specific nutrient demands (e.g. for breeding or moulting).

\section{Conclusions}

The retention or planting of bird-preferred fruiting trees for shade, as ornamentals, in windrows to decrease wind erosion and moisture loss, or as fencerows can be a powerful management tool for enhancing significantly disturbed or converted habitats for birds (Petit and Petit 2003). Birds seem to concentrate in areas where resources are concentrated, and the high density of fruit in managed shelterbelts should decrease competition among them and increase their rates of weight gain (Martin and Karr 1986, Rey 1995, Parrish 2000). If enriched shelterbelts were established over wide geographic areas, then birds should be able to locate good stopover habitat quickly regardless of where inclement weather might steer them (Moore and Simons 1992, Moore et al. 1995). Such habitats should also be relatively easy to establish in strategic areas either just before the commencement of a barrier crossing or just after its completion (e.g. on opposite sides of the Gulf of Mexico; Petit 200o). The amount of habitat required would be significantly less than that required with the protection of natural areas, as well as compatible with agricultural and other kinds of development.

Plant species could be chosen to focus on particular species or categories of birds. An obvious target group might be species that occupy a habitat whose extent or quality in a region has been significantly reduced or degraded. Likewise, the birds could be one or several species of special interest to the country or local area where the work is being done (cf. Stotz et al. 1996). However, the technique will probably be most useful for birds with limited nutrient and energetic demands. These include wintering birds, which generally do not engage in especially demanding life-cycle activities (except perhaps for moult), and migrants en route, which have high energy demands but for relatively brief periods as they pass through an area.

Selective plantings have been used extensively by nature lovers to attract selected species of birds to parks and gardens. Likewise, the planting of shelterbelts around fields to decrease soil erosion has been practised for centuries. The results of this study suggest that these two practices, which developed primarily in temperate regions, could be combined for the benefit of both soils and target groups of avian frugivores in the tropics. The strength of this approach is that food for many different species and seasons can be managed at the same time.

Appendix. Bird species feeding on fruits of Cymbopetalum mayanum, Bursera simaruba and Trophis racemosa, in undisturbed $(U)$ and disturbed $(D)$ habitats in the vicinity of the Chajul Tropical Biology Station, Chiapas, Mexico

\begin{tabular}{|c|c|c|c|}
\hline Species & C. mayanum & B. simaruba & T. racemosa \\
\hline Plain Chachalaca (Ortalis vetula) & & & $\mathrm{D}$ \\
\hline Olive-throated Parakeet (Aratinga nana) & & $\mathrm{D}$ & \\
\hline Red-lored Parrot (Amazona autumnalis) & $\mathrm{D}$ & $\mathrm{D}$ & \\
\hline Squirrel Cuckoo (Piaya cayana) & & & $\mathrm{D}$ \\
\hline Slaty-tailed Trogon (Trogon massena) & & & $\mathrm{U}$ \\
\hline Citreoline Trogon (Trogon citreolus) & & $\mathrm{D}$ & $\mathrm{D}$ \\
\hline Blue-crowned Motmot (Momotus momota) & $\mathrm{D}$ & & \\
\hline Collared Araçari (Pteroglossus torquatus) & & $\mathrm{U}, \mathrm{D}$ & $\mathrm{D}$ \\
\hline Keel-billed Toucan (Ramphastos sulfuratus) & $\mathrm{D}$ & $\mathrm{D}$ & \\
\hline Black-cheeked Woodpecker (Melanerpes pucherani) & $\mathrm{U}, \mathrm{D}$ & $\mathrm{D}$ & $\mathrm{D}$ \\
\hline Golden-fronted Woodpecker (Melanerpes aurifrons) & $\mathrm{D}$ & & \\
\hline Pale-billed Woodpecker (Campephilus guatemalensis) & $\mathrm{U}$ & & \\
\hline
\end{tabular}


Species

$\begin{array}{lll}\text { C. mayanum } & \text { B. simaruba } & \text { T. racemosa }\end{array}$

Ochre-bellied Flycatcher (Mionectes oleagineus)

Bright-rumped Attila (Attila spadiceus)

U, D

Rufous Mourner (Rhytipterna holerythra)

Dusky-capped Flycatcher (Myiarchus tuberculifer)*

U, D

U, D

$\mathrm{U}, \mathrm{D}$

Great crested Flycatcher (Myiarchus crinitus)*

Brown-crested Flycatcher (Myiarchus tyrannulus*

Great Kiskadee (Pitangus sulphuratus)

Boat-billed Flycatcher (Megarynchus pitangua)

Social Flycatcher (Myiozetetes similis)

Sulphur-bellied Flycatcher (Myiodynastes luteiventris)*

Tropical Kingbird (Tyrannus melancholicus) ${ }^{*}$

Eastern Kingbird (Tyrannus tyrannus) ${ }^{*}$

Thrush-like Shiffornis (Schiffornis turdinus)

Rufous Piha (Lipaugus unirufus)

Gray-collared Becard (Pachyramphus major)

Masked Tityra (Tityra semifasciata)

Black-crowned Tityra (Tityra inquisitor)

White-collared Manakin (Manacus candei)

Red-capped Manakin (Pipra mentalis)

Yellow-throated Vireo (Vireo flavifrons) ${ }^{*}$

$\mathrm{D}$

U, D

$\mathrm{D}$

D

U, D

$\mathrm{D}$

D

D

D

$\mathrm{D}$

U, D

D

$\mathrm{D}$

U, D

Warbling Vireo (Vireo gilvis)*

Red-eyed Vireo (Vireo olivaceous)*

Yellow-green Vireo (Vireo flavoviridis)*

Vireo sp. (Vireo sp.)

D

D

U, D

D

$\mathrm{U}$

D

$\mathrm{D}$

U, D

D

U, D

$\mathrm{U}$

U, D

Green Shrike-vireo (Vireolanius pulchellus)

Brown Jay (Cyanocorax morio)

Swainson's Thrush (Catharus ustulatus)*

Wood Thrush (Hylocichla mustelina) ${ }^{*}$

Clay-coloured Robin (Turdus grayi)

Gray Catbird (Dumetella carolinensis)*

Tennessee Warbler (Vermivora peregrina)*

Yellow Warbler (Dendroica petechia)*

Chestnut-sided Warbler (Dendroica pensylvanica)*

Ovenbird (Seiurus aurocapillus)*

Kentucky Warbler (Oporornis formosus)*

Black-throated Shrike-tanager (Lanio aurantius)

Red-throated Ant-tanager (Habia fuscicauda)

Summer Tanager (Piranga rubra)*

Scarlet Tanager (Piranga olivacea) ${ }^{*}$

Western Tanager (Piranga ludoviciana)*

Crimson-collared Tanager (Ramphocelus sanguinolentus)

D

U, D

$\mathrm{U}$

U, D

D

$\mathrm{D}$

U

$\mathrm{D}$

$\mathrm{D}$

U, D

$\mathrm{D}$

D

Passerini's Tanager (Ramphocelus passerinii)

Blue-gray Tanager (Thraupis episcopus)

Yellow-winged Tanager (Thraupis abbas)

Golden-hooded Tanager (Tangara larvata)

U, D

D

U

U, D

D

U, D

U, D

D

D

D

$\mathrm{U}$

D

U

$\mathrm{U}$

U, D

$\mathrm{U}$

U, D

U, D

U, D

$\mathrm{D}$

$\mathrm{D}$

U

U, D

D

$\mathrm{D}$

Red-legged Honeycreeper (Cyanerpes cyaneus)

Orange-billed Sparrow (Arremon aurantiirostris)

Grayish Saltator (Saltator coerulescens)

Buff-throated Saltator (Saltator maximus)

Black-headed Saltator (Saltator atriceps)

Black-faced Grosbeak (Caryothraustes poliogaster)

Rose-breasted Grosbeak (Pheucticus ludovicianus)*

Blue-black Grosbeak (Cyanocompsa cyanoides)

D

D

$\mathrm{D}$

$\mathrm{U}$

Indigo Bunting (Passerina cyanea)*

Melodious Blackbird (Dives dives)*

Black-cowled Oriole (Icterus dominicencis) 
Orchard Oriole (Icterus spurius) ${ }^{*}$

Yellow-tailed Oriole (Icterus mesomelas)

Baltimore Oriole (Icterus galbula)*

Yellow-billed Cacique (Amblycercus holosericeus)

Montezuma Oropendola (Psarocolius montezuma)

\section{$\mathrm{D}$}

U, D D

$\mathrm{U}$

*Denotes Nearctic migrant.

\section{Acknowledgements}

I thank S. Ochoa Gaona and S. Smith for help with plant identifications. Voucher specimens are deposited in the following herbaria: ECOSUR, Colegio de la Frontera Sur, San Cristóbal de las Casas (ECO-SC-He), Mexico; National Herbarium, Universidad Nacional Autónoma de México (UNAM), Mexico City (MEXU); California Academy of Sciences, San Francisco, California (CAS); and National Museum of Natural History, Smithsonian Institution, Washington, D.C. (U.S.). I also thank P. Wenninger and L. Marquez-Valdelamar for hours of tree watching; G. Domínguez Vásquez for assistance with the fruit-transect surveys and collection of phenological data; R. Greenberg, N. V. L. Brokaw, E. P. Mallory and P. W. Alcorn for permission to use unpublished data; and R. W. McDiarmid for commenting on an early draft of the manuscript. I am grateful to the Mexican Secretariat of Urban Development and Ecology (SEDUE) for authorizing my research in México; to ECOSUR, Conservation International and R. Greenberg for help with logistics; and to R. Medellin and UNAM for permission to work at the Chajul Tropical Biology Station.

\section{References}

American Ornithologists' Union (1998) Check-list of North American birds. Seventh edition. Washington, D.C.: American Ornithologists' Union.

Askins, R. A., Lynch, J. F. and Greenberg, R. (1990) Population declines in migratory birds in eastern North America. Curr. Ornithol. 7: 1-57.

Barrow, W. C. Jr, Chen, C.-C., Hamilton, R. B., Ouchley, K. and Spengler, T. J. (200o) Disruption and restoration of en route habitat, a case study: the Chenier Plain. Stud. Avian Biol. 20: 71-87.

Borgmann, K. I., Pearson, S. F., Levy, D. J. and Greenberg, C. H. (2004) Wintering YellowRumped Warblers (Dendroica coronata) track manipulated abundance of Myrica cerifera fruits. Auk 121: 74-87.

Castillo-Campos, G. and Narave Flores, H. (1992) Contribución al conocimiento de la vegetación de la Reserva Biósfera Montes Azules, Selva Lacandona, Chiapas, México. Pp. $51-85$ in M. A. Vásquez Sánchez and M. A. Ramos Olmos, eds. Reserva de la
Biósfera Montes Azules, Selva Lacandona: Investigación para su Conservación. San Cristóbal de las Casas, Chiapas, Mexico: Centro de Estudios para la Conservación de los Recursos Naturales, A.C. Publ. Especial Ecósfera No. 1.

Coates-Estrada, R. and Estrada, A. (1988) Frugivory and seed dispersal in Cymbopetalum baillonii (Annonaceae) at Los Tuxtlas, Mexico. J. Trop. Ecol. 4: 157-172.

Cristol, D. A., Baker, M. B. and Carbone, C. (1999) Differential migration revisited: latitudinal segregation by age and sex class. Curr. Ornithol. 15: 33-88.

Croat, T. B. (1978) Flora of Barro Colorado Island. Stanford, California: Stanford University Press.

Dobson, A., Ralls, K., Foster, M., Soulé, M. E., Simberloff, D., Doak, D., Estes, J. A., Mills, L. S., Mattson, D., Dirzo, R., Arita, H., Ryan, S., Norse, E. A., Noss, R. F. and Johns, D. (1999) Corridors: reconnecting fragmented landscapes. Pp. 129-170 in 
M. E. Soulé and J. Terborgh, eds. Continental conservation. Washington, D.C.: Island Press.

Faaborg, J. (2002) Saving migrant birds. Austin, Texas: University of Texas Press.

Foster, M. S. (1987) Feeding methods and efficiencies of selected frugivorous birds. Condor 89: 566-580.

Fragoso, C. and Lavelle, P. (1987) The earthworm community of a Mexican tropical rain forest (Chajul, Chiapas). Pp. 281-295 in A. M. Bonvicini Pagliai and P. Omodeo, eds. On earthworms. Italian Union of Zoology (Natural Sci. Ser.): Selected Symposia and Monogr. 2. Modeno, Italy: Mucchi Editore.

González-García, F. (1992) Aves de la Selva Lacandona, Chiapas, México. Pp. 173-200 in M. A. Vásquez Sánchez and M. A. Ramos Olmos, eds. Reserva de la Biósfera Montes Azules, Selva Lacandona: investigación para su conservación. San Cristóbal de las Casas, Chiapas, Mexico: Centro de Estudios para la Conservación de los Recursos Naturales, A.C. Publ. Especial Ecósfera No. 1 .

González-García, F., Rangel Salazar, J. L. (1999) SE-17, Montes Azules. In H. Benítez, C. Arizmendi and L. Marquez. Base de Datos de las AICAS. CIPAMEX, CONABIO, FMCN, y CCA. URL: http://conabioweb.conabio. gob.mx/aicas/doctos/aicas.html (accessed 10 April 2006).

Google Earth (2006) URL: http://earth. google.com/ (accessed 13 April 2006).

Graham, C., Martínez, J. E. and Cruz-Paredes, L. (2002) Use of fruiting trees by birds in continuous forest and riparian forest remnants in Los Tuxtlas, Veracruz, Mexico. Biotropica 34: 589-597.

Green, R. E., Osborne, P. E. and Sears, E. J. (1994) The distribution of passerine birds in hedgerows during the breeding season in relation to characteristics of the hedgerow and adjacent farmland. J. Appl. Ecol. 31: 677-692.

Greenberg, R. (1992) Forest migrants in nonforest habitats on the Yucatan Peninsula. Pp. $273^{-286}$ in J. M. Hagan III and D. W. Johnston, eds. Ecology and conservation of Neotropical migrant landbirds. Washington, D.C.: Smithsonian Institution Press.
Greenberg, R., Foster, M. S. and MarquezValdelamar, L. (1995) The role of the White-eyed Vireo in the dispersal of Bursera fruit on the Yucatan Peninsula. J. Trop. Ecol. 11: 619-639.

Greenberg, R., Bichier, P., Cruz Angon, A. and Reitsma, R. (1997) Bird populations in shade and sun coffee plantations in Central Guatemala. Conserv. Biol. 11: 448-459.

Grissell, E. E. and Foster, M. S. (1996) A new Bephratelloides (Hymenoptera: Eurotomidae) from seeds of Cymbopetalum (Annonaceae) in Mexico. Proc. Entomol. Soc. Washington 98: 256-263.

Haas, C. A. (1995) Dispersal and use of corridors by birds in wooded patches on an agricultural landscape. Conserv. Biol. 9: $845-854$.

Hagan, J. M. III and Johnston, D. W. eds. (1992) Ecology and conservation of Neotropical migrant landbirds. Washington, D.C.: Smithsonian Institution Press.

Howe, H. F. (1979) Fear and frugivory. Am. Nat. 114: 925-931.

Hutto, R. L. (2000) On the importance of en route periods to the conservation of migratory birds. Stud. Avian Biol. 20: 109-114.

Johnson, N. K. (1965) Differential timing and routes of the spring migration in the Hammond Flycatcher. Condor 67: 423-437.

Little, E. L. Jr and Wadsworth, F. H. (1964) Common trees of Puerto Rico and the Virgin Islands. Agriculture Handbook No. 249. Washington, D.C.: U.S. Department of Agriculture, Forest Service.

Little, E. L. Jr, Woodbury, R. O. and Wadsworth, F. H. (1974) Trees of Puerto Rico and the Virgin Islands. Volume 2. Agriculture Handbook No. 449. Washington, D.C.: U.S. Department of Agriculture, Forest Service.

Martin, T. E. and Karr, J. R. (1986) Patch utilization by migrating birds: resource oriented? Orn. Scan. 17: 165-174.

Martin, T. E. and Karr, J. R. (1990) Behavioral plasticity of foraging maneuvers of migratory warblers: multiple selection periods for niches? Stud. Avian Biol. 13: 353-359.

Martinez, M. (1969) Las plantas medicinales de México. Fifth edition. México, D.F.: Andres Botas, Eds. Botas. 
Miranda, F. (1953) La vegetación de Chiapas. Part 2. Tuxtla Gutierrez, Chiapas, Mexico: Eds. del Gobierno del Estado, Sec. Autográfica, Depto. Prensa y Turísmo.

Moore, F. R. (1991) Ecophysiological and behavioral response to energy demand during migration. Acta XX Congressus Internationalis Ornithologici 20: 753-760.

Moore, F. R. and Aborn, D. A. (2000) Mechanisms of en route habitat selection: how do migrants make habitat decisions during stopover? Stud. Avian Biol. 20: 34-42.

Moore, F. R. and Simons, T. R. (1992) Habitat suitability and stopover ecology of Neotropical landbird migrants. Pp. 345-355 in J. M. Hagan III and D. W. Johnston, eds. Ecology and conservation of Neotropical migrant landbirds. Washington, D.C.: Smithsonian Institution Press.

Moore, F. R., Gauthreaux, S. A. Jr, Kerlinger, P. and Simons, T. R. (1995) Habitat requirements during migration: important link in conservation. Pp. 121-144 in T. E. Martin and D. M. Finch, eds. Ecology and management of Neotropical migratory birds. New York: Oxford University Press.

Morton, E. S. (1980) Adaptations to seasonal changes by migrant land birds in the Panama Canal Zone. Pp. $437-453$ in A. Keast and E. S. Morton, eds. Migrant birds in the Neotropics: ecology, behavior, distribution, and conservation. Washington, D.C.: Smithsonian Institution Press.

Murray, N. A. (1993) Revision of Cymbopetalum and Porcelia (Annonaceae). Syst. Bot. Monogr. 40: 1-121.

Paine, R. T. (1971) The measurement and application of the calorie to ecosystem problems. Annu. Rev. Ecol. Syst. 2: 145-164.

Parker, T. A. III, Stotz, D. F. and Fitzpatrick, J. W. (1996) Part 4. Ecological and distributional databases. Pp. 112-436 in D. F. Stotz, J. W. Fitzpatrick, T. A. Parker III and D. K. Moskovits, eds. Neotropical birds: ecology and conservation. Chicago, Illinois: University of Chicago Press.

Parrish, J. D. (2000) Behavioral, energetic, and conservation implications of foraging plasticity during migration. Stud. Avian Biol. 20: $53-70$.
Pennington, T. D. and Sarukhan, J. (1968) Árboles tropicales de México. Rome, Italy: Instituto Nacional Investigaciones Forestales, Mexico, and Organización de las Naciones Unidas para la Agricultura y la Alimentación.

Peterjohn, B. G., Sauer, J. R. and Robbins, C. S. (1995) Population trends from the North American Breeding Bird Survey. Pp. 3-39 in T. E. Martin and D. M. Finch, eds. Ecology and management of Neotropical migratory birds. New York: Oxford University Press.

Petit, D. R. (200o) Habitat use by landbirds along Nearctic-Neotropical migration routes: implications for conservation of stopover habitats. Stud. Avian Biol. 20: 15-33.

Petit, L. J. and Petit, D. R. (2003) Evaluating the importance of human-modified lands for Neotropical bird conservation. Conserv. Biol. 17: 687-694.

Pulido Salas, M. T. and Serralta Peraza, L. (1993) Lista anotada de las plantas medicinales de uso actual en el Estado de Quintana Roo, México. Chetumal, Quintana Roo, Mexico: Centro de Investigaciones de Qunintana Roo.

Rappole, J. H. (1995) The ecology of migrant birds: a Neotropical perspective. Washington, D.C.: Smithsonian Institution Press.

Rappole, J. H., Morton, E. S., Lovejoy, T. E. III and Ruos, J. L. (1983) Nearctic avian migrants in the Neotropics. Washington, D.C.: U.S. Department of the Interior, Fish and Wildlife Service.

Rey, P. J. (1995) Spatio-temporal variation in fruit and frugivorous bird abundance in olive orchards. Ecology 76: 1625-1635.

Robbins, C. S., Bystrak, D. and Geissler, P. H. (1986) The breeding bird survey: its first fifteen years, 1965-1979. U.S. Department of the Interior, Fish and Wildlife Service, Resource Publ. No. 157.

Robbins, C. S., Sauer, J. R., Greenberg, R. S. and Droege, S. (1989) Population declines in North American birds that migrate to the Neotropics. Proc. Natl. Acad. Sci. USA 86: $7658-7662$.

Robinson, S. K. and Wilcove, D. S. (1994) Forest fragmentation in the temperate zone 
and its effects on migratory songbirds. Bird Conserv. Int. 4: 233-249.

Sauer, J. R. and Droege, S. (1992) Geographic patterns in population trends of Neotropical migrants in North America. Pp. $26-42$ in J. M. Hagan, III and D. W. Johnston, eds. Ecology and conservation of Neotropical migrant landbirds. Washington, D.C.: Smithsonian Institution Press.

Scott, P. E. and Martin, R. F. (1984) Avian consumers of Bursera, Ficus, and Ehretia fruit in Yucatán. Biotropica 16: 319-323.

Standley, P. C. and Steyermark, J. A. (1946) Flora of Guatemala. Fieldiana: Botany 24(IV).

Stotz, D. F., Fitzpatrick, J. W., Parker, T. A. III and Moskovits, D. K. (1996) Neotropical birds: ecology and conservation. Chicago, Illinois: University of Chicago Press.

Turček, F. J. (1963) Color preference in fruitand seed-eating birds. Pp. 285-292 in Proc. XIII Ornithol. Congr. Vol. 1. Washington, D.C.: American Ornithologists' Union.

Vásquez Sánchez, M. A. (1992) La Reserva de la Biósfera Montes Azules: antecedentes. Pp. ${ }^{19-38}$ in M. A. Vásquez Sánchez and M. A. Ramos Olmos, eds. Reserva de la Biósfera Montes Azules, Selva Lacandona: investigación para su conservación. San Cristóbal de las Casas, Chiapas, Mexico: Centro de Estudios para la Conservación de los Recursos Naturales, A.C. Publ. Especial Ecósfera No. 1.

Vásquez Sánchez, M. A. and Ramos Olmos, M. A., eds. (1992) Reserva de la Biósfera Montes Azules, Selva Lacandona: investigación para su conservación. San Cristóbal de las Casas, Chiapas, Mexico: Centro de Estudios para la Conservación de los Recursos Naturales, A.C. Publ. Especial Ecósfera No. 1.

Voelker, G. and Rohwer, S. (1998) Contrasts in scheduling of moult and migration in eastern and western warbling-vireos. Auk 115: 142-155.

Warkentin, I. G., Greenberg, R. and Ortiz, J. S. (1995) Songbird use of gallery woodlands in recently cleared and older settled landscapes of the Selva Lacandona, Chiapas, Mexico. Conserv. Biol. 9: 1095-1106.

Wiedenfeld, D. A., Messick, L. R. and James, F. J. (1992) Population trends in 65 species of North American birds, including Neotropical migrants, temperate-zone migrants, and resident species, 1966-1990. Final report to the National Fish and Wildlife Foundation, Neotropical Migratory Bird Conservation Program, Contract \#91-017. Washington, D.C.

Woodrey, M. S. (2000) Age-dependent aspects of stopover biology of passerine migrants. Stud. Avian Biol. 20: 43-52.

\section{MERCEDES S. FOSTER}

USGS Patuxent Wildife Research Center, National Museum of Natural History, P. O. Box 37012 Washington, DC 20013-7012, USA. E-mail: fosterm@si.edu.

Received 5 July 2005; revision accepted 2 May 2006 